\title{
Beta 2 adrenergic receptor polymorphisms, at codons 16 and 27, and bronchodilator responses in adult Venezuelan asthmatic patients
}

\author{
Nancy Larocca ${ }^{\mathrm{a}, \mathrm{b}}$, Dolores Moreno ${ }^{\mathrm{b}}$, Jenny Valentina Garmendia ${ }^{\mathrm{a}}$, Olga Velasquez ${ }^{\mathrm{a}}$, Joana Martin-Rojo ${ }^{\mathrm{a}}$, Carlos Talamoc, \\ Alexis Garcia ${ }^{a}$, Juan Bautista De Sanctis ${ }^{\mathrm{a}}$
}

Background. One of the gene polymorphisms often studied in asthmatic patients is the $\beta 2$ adrenergic receptor (ADR $\beta 2$ ). Even though in the Venezuelan Mestizo population there is a high incidence of asthma, there are no direct reports of ADR $\beta 2$ gene polymorphism, and treatment response. The aim of this study was to assess, in this population, the gene frequency of ADR 32 polymorphisms at codons $16 \mathrm{Arg} / \mathrm{Gly}$ and $27 \mathrm{Gln} / \mathrm{Glu}$, allergen sensitization, and its relationship to bronchodilator response.

Methods. Purified genomic DNA was obtained form 105 Mestizo asthmatic and 100 Mestizo healthy individuals from Venezuela. The two polymorphisms were assessed by PCR-RFLP. Patient sensitization to aeroallergens and their response to bronchodilatation were correlated.

Results. Significant differences between patients and controls were recorded in: 1) the prevalence of Arg/Arg at codon $16(28.6 \%$ in patients vs. $47 \%$ in controls, $P<0.01), 2)$ the frequency of heterozygotes Arg/Gly ( $55 \%$ in patients vs. $35 \%$ in controls, $P<0.01)$. Conversely, no differences in polymorphism frequencies were found at codon 27 . The haplotypes $\mathrm{Arg} / \mathrm{Gly}$-Gln/Gln were more common in patients than controls $(P<0.01)$, whereas the Arg/Arg-Gln/Glu combination prevailed in the control group $(P<0.01)$. The $\mathrm{Arg} / \mathrm{Gly}$ and $\mathrm{Gln} / \mathrm{Glu}$ genotypes were associated with better responses after salbutamol. The asthmatic homozygotes Arg/Arg have higher sensitivity to aeroallergens.

Conclusion. The difference in Arg/Arg frequency between groups suggests that this could be a protective genotype although the asthmatic group had a higher sensitivity to aeroallergens. The asthmatic heterozygotes had better bronchodilator responses than the homozygotes.

Key words: aeroallergen, asthma, $\beta 2$ adrenergic receptors, bronchodilator response, gene polymorphism

Received: January 4, 2012; Accepted with revision: July 27, 2012; Available online: November 2, 2012 http://dx.doi.org/10.5507/bp.2012.084

aInstitute of Immunology, Faculty of Medicine, Universidad Central de Venezuela, Apartado 50109, Sabana Grande, Caracas, Venezuela 'Institute of Experimental Medicine, Faculty of Medicine, Universidad Central de Venezuela, Apartado 50109, Sabana Grande, Caracas, 'Department of Pneumology, Luis Razetti School of Medicine, University Hospital, Faculty of Medicine, Universidad Central de Venezuela, Caracas

Corresponding author: Juan Bautista De Sanctis, e-mail: sanctisj@gmail.com

\section{INTRODUCTION}

Asthma is a highly prevalent and complex disease in which multiple interacting genes and environmental factors are involved ${ }^{1}$. Evidence shows that alterations of adrenergic $\beta-2$ receptors (ADR $\beta 2)$ can modulate the severity of asthma and the response to treatment, which can be highly variable and difficult to predict ${ }^{2-7}$. Nevertheless, it has been shown that: 1) In the LARGE multicenter study, asthmatics with $\mathrm{Arg} / \mathrm{Arg}$ homozygous genotype, receiving inhaled corticosteroids, experience no change in hyperresponsiveness status even when long acting $\beta 2$ agonists were used $\left.{ }^{8} ; 2\right)$ a combination of salmeterol plus inhaled corticosteroid in the patients Gly/Gly, at amino acid 16 increased 2.4 times the PC20, resulted in decreased bronchial hyperresponsiveness ${ }^{5,8}$; 3) the Gly16/Gln 27 haplotype was inversely associated with hyperresponsiveness to methacholine, while the Arg 16/Gln27 haplotype was associated with a greater degree of hyperresponsiveness ${ }^{9}$, and 4) children homozygous and heterozygous for $\operatorname{Arg} 16$ had higher bronchodilator responses than Gly 16 homozygotes patients $^{10}$. These findings correspond to Caucasians, however, in Venezuela there is a high prevalence of asthma and a large Mestizo population which seem to have a high genetic segregation ${ }^{11-13}$. The relevance of these polymorphisms in various populations and its clinical relevance so far are unknown ${ }^{2}$. In the present study, the polymorphisms at amino acids 16 and 27 of ADR $\beta 2$ were assessed along with clinical, paraclinical parameters and lung function in Venezuelan Mestizo asthmatic patients.

\section{METHODS}

All participants (205) gave written consent to enter the study according to instructions approved by the Ethics and Bioethics Committee of the Institute of Immunology, and of the Venezuelan Foundation of Science and Technology (FONACIT). Genomic DNA was isolated from blood using the QIAmp ${ }^{\circledR}$ DNA Mini kit (Qiagen ${ }^{\circledR}$ ), of 105 individuals diagnosed with asthma according to GINA (ref. ${ }^{14}$ ) guidelines and 100 control subjects with 
no history of asthma or COPD. The groups were gender, and aged matched (between 18 and 60 years old) and third-generation Venezuelan. A medical history and spirometry (forced vital capacity-FVC-forced expiratory volume in one second-FEV1, and FEV1/FVC ratio) was performed for all patients and controls. For the diagnosis of asthma the ATS criteria was used. A positive response to bronchodilator was considered (salbutamol), when a change in FEV1 was greater than or equal to $12 \%$ and at least $200 \mathrm{cc}$.

Total serum IgE was assessed by a commercial kit (Calbiotech, USA). Skin Prick tests for different aeroallergens (Dermatophagoides, Blomia, Blattella, dog, cat, latex, wool, mixed pollens, mixed feathers, mixed fungi spores) were performed in all patients by a commercial kit Alk-ABello ${ }^{\circledR}$ (Spain).

Gene amplification of ADR $\beta 2$ polymorphic regions encoding positions for the amino acids 16 and 27 was performed according to the protocol of Martinez et al. ${ }^{10}$. The two polymorphisms were identified using PCR-RFLP test. The amplification of the genetic region of ADR $\beta 2$ using the PCR technique for each of the samples was performed in a final volume of $50 \mu \mathrm{L}$ with: $300-500 \mathrm{ng}$ of genomic DNA, $1.5 \mathrm{mM}$ magnesium chloride, $0.2 \mathrm{mM}$ of each dNTP, $10 \mathrm{mM}$ Tris. $\mathrm{HCl}, 50 \mathrm{mM} \mathrm{KCl}$ and $0.2 \mathrm{uM}$ of each primer, sense: 5'-GCCTTCTTGCTGGCACCCCAT-3' and antisense: 5'- CAGACGCTCGAACTTGGCCATG-3'. The PCR was performed on Peltier Thermal Cycler PTC200 thermocycler (MJ Research) under the following conditions: an initial denaturation at $94^{\circ} \mathrm{C}$ for $2 \mathrm{~min}$ followed by 40 cycles of $94{ }^{\circ} \mathrm{C}$ for $40 \mathrm{~s}, 64^{\circ} \mathrm{C}$ for $40 \mathrm{~s}$ and $72{ }^{\circ} \mathrm{C}$ for $50 \mathrm{~s}$ followed by a final extension phase at $72{ }^{\circ} \mathrm{C}$ for $5 \mathrm{~min}$. The PCR product of $168 \mathrm{bp}$ was digested with $2 \mathrm{U}$ of $\mathrm{NcoI}$ restriction enzyme (New England Biolabs) for the identification of polymorphism corresponding to the codon 16 and $0.5 \mathrm{U}$ of $B b v \mathrm{I}$ restriction enzyme (New England Biolabs) for identification of the polymorphism corresponding to the codon 27 . The restriction products were run on agarose gels $4 \%$ to $100 \mathrm{~V}$ for 45 min with subsequent ethidium bromide staining) and visualization on a UV light transilluminator $\left(\right.$ Bio-Rad $\left.^{\circledR}\right)$. We confirmed the specificity of amplified and presence of two polymorphisms by sequencing performed by a four capillary sequencer from Applied Biosystems. The rate of success/ failure compared RFLP to sequencing was $98 \%$.

\section{Statistical analysis}

The gene frequencies of polymorphisms in each group were calculated by standard method ${ }^{15}$. A confidence interval of $95 \%$, according to the method of Wilson with correction for continuity, was used ${ }^{15}$. The PHASE program ${ }^{16}$ was used to calculate the frequency of haplotypes (Bayesian method using the Markov chain-Monte Carlo algorithm). The $95 \%$ confidence interval of the frequency of individual haplotypes was estimated by the Chi squared test.

\section{RESULTS}

The characteristics of patients and controls are shown in Table 1. Gender and age did not differ significantly between the groups. As expected, in the asthmatic group, the values of FEV1 and FEV1/FVC were significantly lower than controls $(P<0.0001)$. Most patients had moderate persistent asthma (42.9\%). Allergic asthma was more prevalent $(86.7 \%)$ than intrinsic $(5.7 \%)$, mixed $(5.7 \%)$ or occupational $(0.9 \%)$; allergic rhinitis $(50.5 \%)$ and atopic dermatitis $(10.5 \%)$ were the most frequent symptoms recorded. Moreover, $95 \%$ of asthmatics were positive to at least one aeroallergen in skin tests. The most common sensitizations in allergic asthmatics were: house dust mites (56\% to Dermatophagoides pteronyssinus (Dp), 23\% to Dermatophagoides pharinae (Df)), $38.5 \%$ to cockroach

Table 1. Characteristics of patients (according gina guidelines) and controls.

\begin{tabular}{lcc}
\hline & $\begin{array}{c}\text { Patients } \\
(\mathrm{n}=105)\end{array}$ & $\begin{array}{c}\text { Controls } \\
(\mathrm{n}=100)\end{array}$ \\
\hline $\mathrm{N}$ & 105 & 100 \\
Female Gender & $76(72.4 \%)$ & $77(77.0 \%)$ \\
Age X $\pm \mathrm{SD}$ & $44.4 \pm 15.2$ & $42.6 \pm 13.9$ \\
FEV1 $(\mathrm{L}) \overline{\mathrm{X}} \pm \mathrm{SD}$ & $1.9 \pm 0.6 *$ & $3.06 \pm 0.8$ \\
FEV1/FVC $(\%) \overline{\mathrm{X}} \pm \mathrm{SD}$ & $65.9 \pm 10.0 *$ & $81.2 \pm 5.5$ \\
Total IgE IU/ml X $\pm \mathrm{SD}$ & $473.0 \pm 598.6^{*}$ & $123.0 \pm 174.0$ \\
Smokers & $37(35.2 \%)^{*}$ & 0 \\
Rhinitis & $53(50.5 \%) *$ & 0 \\
Atopic Dermatitis & $11(10.5 \%)^{*}$ & 0 \\
Mild Intermittent Asthma. & $13(12.4 \%)$ & - \\
Mild Persistent Asthma. & $18(17.1 \%)$ & - \\
Moderate Persistent Asthma & $45(42.9 \%)$ & - \\
Severe Asthma & $29(27.6 \%)$ & - \\
\hline
\end{tabular}

Significant differences are recorded in several parameters, ${ }^{*} P<0.0001$. 
Table 2. Polymorphism at codons 16 and 27 of $\beta 2$ adrenergic receptor in patients with asthma and controls.

\begin{tabular}{ccc}
\hline Polymorphism & $\begin{array}{c}\text { Patients } \\
\mathrm{n}(\%)\end{array}$ & $\begin{array}{c}\text { Controls } \\
\mathrm{n}(\%)\end{array}$ \\
\hline 16 & $30(28.6)$ & $47(47) *$ \\
$\mathrm{Arg} / \mathrm{Arg}$ & $17(16.2)$ & $18(18)$ \\
Gly/Gly & $58(55.2)$ & $35(35) *$ \\
$\mathrm{Arg} /$ Gly & & $10(10.0)$ \\
27 & $11(10.5)$ & $30(30.0)$ \\
Glu/Glu & $37(35.2)$ & $60(60.0)$ \\
Gln/Gln & $57(54.3)$ & \\
Gln/Glu &
\end{tabular}

Significant differences were observed at codon 16 between controls and patients * $P<0.01$.

Table 3. Haplotypes at codons 16 and 27 of $\beta 2$ adrenergic receptor in patients with asthma and controls.

\begin{tabular}{cccccc}
\hline Polymorphism & $\begin{array}{c}\text { Patients } \\
\text { n }(\%)\end{array}$ & $\begin{array}{c}\text { Controls } \\
\text { n } \%)\end{array}$ & OR & CI & $P$ \\
\hline Arg/Arg-Gln/Gln & $10(9.5)$ & $18(18)$ & 0.54 & $0.27-1.08$ & NS \\
Gly/Gly-Glu/Glu & $3(2.9)$ & $4(4)$ & 1.42 & $0.39-5.08$ & NS \\
Arg/Arg-Glu/Glu & $3(2.9)$ & $2(4)$ & 0.69 & $0.15-3.17$ & NS \\
Gly/Gly-Gln/Gln & $3(2.9)$ & $3(3)$ & 1.05 & $0.27-4,11$ & NS \\
Arg/Gly-Gln/Glu & $29(27.6)$ & $22(22)$ & 0.74 & $0.43-1.26$ & NS \\
Arg/Gly-Glu/Glu & $5(4.8)$ & $4(4)$ & 0.83 & $0.27-2.57$ & NS \\
Arg/Gly-Gln/Gln & $24(22.9)$ & $9(9)$ & 0.33 & $0.17-0.67$ & $<0.01$ \\
Arg/Arg-Gln/Glu & $17(16.2)$ & $27(27)$ & 1.92 & $1.08-3.39$ & $<0.01$ \\
Gly/Gly-Gln/Glu & $11(10.5)$ & $11(11)$ & 1.06 & $0.50-2.22$ & NS \\
\hline
\end{tabular}

OR: Odds Ratio, CI: Confidence Interval. NS stands for not significant.

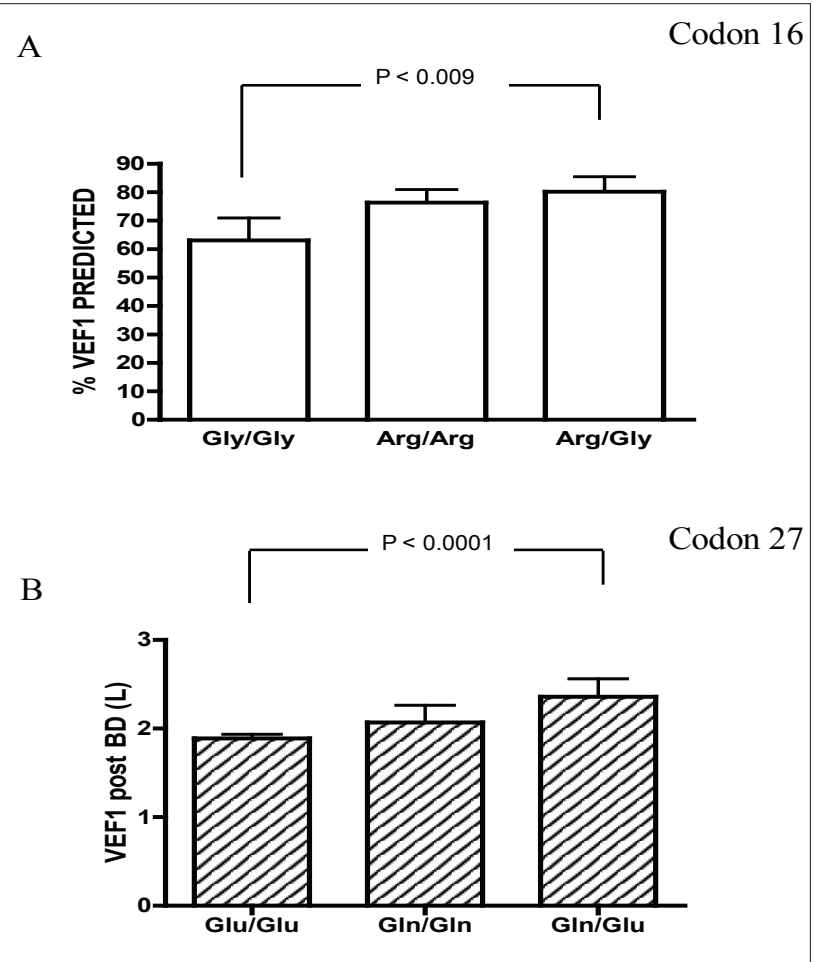

Fig. 1. Association between bronchodilator response and gene polymorphism.
(B. germanica), 23\% to Blomia tropicalis, $28 \%$ to Mold I panel, 33\% to cat and latex, 25.6\% Pollen V panel, and $20.5 \%$ to Dog. The rest of the allergens were on or below $10 \%$.

Table 2 shows the frequency for both polymorphisms at codons 16 and 27. The Arg/Arg homozygous was more frequent in the control group as compared to the patient group, $47.0 \%$ vs $28.6 \%, P<0.01$, and the opposite was for the Arg/Gly heterozygous, $35.0 \%$ vs. $55.2 \%$ ( $P<0.01)$. No differences were found in the polymorphism at amino acid 27. No relationship was found between the different polymorphisms (16 and 27) and asthma severity; however, nocturnal symptoms predominated among patients with 16 Gly/Gly. In this group, $70.6 \%$ had nocturnal symptoms $(P=0.05)$.

Part A. Association between the percentage of predicted value (PV) in FEV1 after bronchodilator response (BD) and $\beta 2 \mathrm{AR}$ polymorphism at codon 16 . Significant differences are observed in the predicted value between the homozygotes Gly/Gly and the heterozygotes Arg/Gly, $(P<0.009)$.

Part B. Association between FEV1 after bronchodilator response (BD) and $\beta 2 A R$ polymorphism at codon 27 . Significant differences are observed in the VEF1 post test between the homozygotes Glu/Glu and the heterozygotes Gln/Glu $(P<0.0001)$. 
In the haplotype analysis, (Table 3), as expected from the previous results, Arg/Gly-Gln/Gln was more prevalent in patients $(22.9 \%)$ than controls $(9 \%),(P<0.01)$, and the haplotype Arg/Arg-Gln/Glu was more frequent in the control group ( $27 \%$ vs. $16.2 \%, P<0.01)$.

The relationship between predicted FEV1 and FEV1 post bronchodilator response and gene polymorphisms are represented in Fig. 1A and 1B. In part A of the figure, even though the parameters of pre-bronchodilator lung function were similar among patients, the group with Gly/ Gly showed a lower percentage of predicted FEV1 post bronchodilator test than the Arg/Gly group $(P<0.009)$. In similar fashion as shown in part B of the figure, the Glu/Glu group showed post bronchodilator FEV1 values significantly less than Gln/Glu heterozygous patients $(P<0.0001)$.

Interestingly, patients Arg/Arg homozygotes were more sensitized to aeroallergens (78\%) than the herterozygotes (40\%) and the Gly/Gly (28\%) counterparts $(P<0.05)$. This effect was not recorded at codon 27 . The significance was lost in the haplotype analysis.

\section{DISCUSSION}

The most common polymorphisms of the ADR $\beta 2$ are at codons 16 and 27 and several studies have suggested that these polymorphisms have a modulatory effect on asthma severity and response to therapy. An association between the Gly at codon 16 and severe asthma, requiring oral corticosteroids, immunotherapy, or both treatments was suggested ${ }^{5}$.

The results of our study showed that the frequency of Arg/Arg at amino acid 16 was higher in the Venezuelan Mestizo normal population and the Arg/Gly heterozygous was more prevalent in our asthmatic population contrasting with reports on Caucasian or Asian populations $^{8-10,17}$. In similar fashion, the haplotype Arg/Arg-Gln/ Glu haplotype appears to protect the Venezuelan Mestizo population from asthma and the haplotype Arg/Gly-Gln/ Gin haplotype appears to increase susceptibility. Probably, these differences are due to the mixture of our population, as demonstrated by the Fortes et al study ${ }^{18}$ in which the Venezuelan Mestizo population with autoimmune hepatitis showed some disease-protective HLA alleles which differ from those reported for Caucasians and Japanese populations ${ }^{18}$.

In several meta-analysis published ${ }^{19-22}$, the authors concluded that genetic polymorphisms of ADR $\beta 2$ do not represent an increased risk for developing asthma, yet are important in therapy outcome. In patients with severe asthma, Park et al. ${ }^{22}$, showed an association between Arg/Gly polymorphism at codon 16 of ADR $\beta 2$ and better response to tiotropium. Probably, our asthmatic population would respond better to anticholinergic agents since this polymorphism is the most prevalent ${ }^{22}$. Moreover, our results with bronchodilator response are in accordance to those reported by Finkelstein, who found a better bronchodilator response in heterozygous carriers at codons 16 and 27 (ref. ${ }^{23}$ ).
We conclude that genetic typing of ADR $\beta 2$ polymorphism may help identify individuals with asthma resistant to $\beta 2$-adrenergic agonists or with severe or difficult to treat asthma. Even though, the Arg/Arg polymorphism at amino acid 16 is common in the healthy Venezuelan Mestizo population, as well as the Arg/Arg-Gln /Glu haplotype, the relevant issue is that in Venezuelan asthmatic Mestizo Arg/Arg are polysensitized to different aeroallergens prevalent in the American tropics and that the patients with Arg/Gly-Gln/Glu haplotype showed the greatest changes in post-bronchodilator FEV1 increasing therapy effectiveness. These results indicate a marked difference in prevalence and therapeutic response compared to other ethnic groups. Further studies are required to ascertain the importance of polymorphism at amino acid 16 as the key element for immune response and treatment outcome in Venezuelan Mestizo population.

\section{ACKNOWLEDGMENT}

Financed by a grant from the Venezuelan Foundation for Research (FONACIT) G-2005-000389 for a project on Pharmacogenetics of chronic respiratory diseases. The authors received the prize of the Venezuelan Foundation of Medications (CAVEME) on 2010.

\section{CONFLICT OF INTEREST STATEMENT}

Author's conflict of interest disclosure: The authors stated that there are no conflicts of interest regarding the publication of this article.

\section{REFERENCES}

1. Zhang J, Paré PD, Sandford A. Recent advances in asthma genetics. Respir Res 2008:9:4-24. doi:10.1186/1465-9921-9-4

2. Carroll CL, Stoltz P, Schramm CM, Zucker AR. Beta2-adrenergic receptor polymorphisms affect response to treatment in children with severe asthma exacerbations. Chest 2009;135:1186-92. doi:10.1378/ chest.08-2041

3. Johnson M. Molecular mechanisms of beta(2)-adrenergic receptor function, response, and regulation. J Allergy Clin Immunol 2006;117:18-24. doi:10.1016/j.jaci. 2005.11.012

4. Martin AC, Zhang G, Rueter K, Khoo SK, Bizzintino J, Hayden CM, Geelhoed GC, Goldblatt J, Laing IA, Le Souëf PN. Beta2adrenoceptor polymorphisms predict response to beta2-agonists in children with acute asthma. J Asthma 2008;45(5):383-8. doi:10.1080/02770900801971792

5. Hizawa N. Pharmacogenetics of $\beta 2$-agonists. Allergol Int 2011;60(3):239-46. doi:10.2332/allergolint.11-RAI-0317

6. Israel E, Chinchilli VM, Ford JG, Boushey HA, Cherniack R, Craig TJ, Deykin A, Fagan JK, Fahy JV, Fish J, Kraft M, Kunselman SJ, Lazarus SC, Lemanske RF Jr, Liggett SB, Martin RJ, Mitra N, Peters SP, Silverman E, Sorkness CA, Szefler SJ, Wechsler ME, Weiss ST, Drazen JMUse of regularly scheduled albuterol treatment in asthma: genotypestratified, randomised, placebo-controlled cross-over trial. Lancet 2004;364:1505-12. doi:10.1016/S0140-6736(04)17273-5

7. Taylor D, Drazen J, Herbison G, Yandava C, Hancox R, Town G. Asthma exacerbations during long term beta agonist use: influence of beta(2) adrenoceptor polymorphism. Thorax 2000;55:762-7. doi: 10.1136/thorax.55.9.762

8. Wechsler ME, Kunselman SJ, Chinchilli VM, Bleecker E, Boushey HA, Calhoun WJ, Ameredes BT, Castro M, Craig TJ, Denlinger L, Fahy 
JV, Jarjour N, Kazani S, Kim S, Kraft M, Lazarus SC, Lemanske RF Jr, Markezich A, Martin RJ, Permaul P, Peters SP, Ramsdell J, Sorkness CA, Sutherland ER, Szefler SJ, Walter MJ, Wasserman SI, Israel E Effect of beta2-adrenergic receptor polymorphism on response to longacting beta2 agonist in asthma (LARGE trial): a genotypestratified, randomised, placebo-controlled, crossover trial. Lancet 2009 21;374(9703):1754-64. doi:10.1016/S0140-6736(09)61492-6

9. Litonjua AA, Silverman EK, Tantisira KG, Sparrow D, Sylvia JS, Weiss ST. Beta 2-adrenergic receptor polymorphisms and haplotypes are associated with airways hyperresponsiveness among nonsmoking men. Chest 2004;126:66-74. doi:10.1378/chest.126.1.66

10. Martinez FD, Graves PE, Baldini M, Solomon S, Erickson R. Association between genetic polymorphisms of the beta2-adrenoceptor and response to albuterol in children with and without a history of wheezing. J Clin Invest 1997;100:3184-8. doi:10.1172/JCI119874

11. Aldrey $O$, De Stefano MV, Carriles A. Prevalencia del Asma Infantil en Caracas, ISAAC 2003. Alergia, Asma e Inmunología 2003;5:33-42.

12. Solé D, Mallol J, Camelo-Nunes IC, Wandalsen GF; Latin American ISAAC Study Group. Prevalence of rhinitis-related symptoms in Latin American children -results of the International Study of Asthma and Allergies in Childhood (ISAAC) phase three. Pediatr Allergy Immuno 2010;21(1Pt2):e127-36. doi:10.1111/j.1399-3038.2009.00947.x

13. Mallol J, Solé D, Baeza-Bacab M, Aguirre-Camposano V, Soto-Quiros M, Baena-Cagnani C; Latin American ISAAC Group. Regional variation in asthma symptom prevalence in Latin American children. J Asthma 2010;47(6):644-50. doi: 10.3109/02770901003686480

14. Bateman ED, Boulet LP, Cruz A, FitzGerald M, Átela T, Levy M, O’Byrne P, Ohta K, Paggario P, Pedersern S, Soto-Quiroz M, Wong G. Pocket Guide for Asthma management and Prevention. For adults and children 5 years and older GINA. 2011. Medical Comunications Resources. http://www.ginasthma.org/uploads/users/files/GINA_ PocketGuide_2011.pdf pp8.

15. Newcombe RG. Improved confidence intervals for the difference between binomial proportions based on paired data. Stat Med 1998; 17:857-72.

16. Stephens M, Smith NJ, Donnelly P. A new statistical method for haplotype reconstruction from population data. Am J Hum Genet 2001;68:978-89.
17. Bleecker ER, Postma DS, Lawrance RM, Meyers DA, Ambrose HJ, Goldman M. Effect of ADRB2 polymorphisms on response to long acting beta2-agonist therapy: a pharmacogenetic analysis of two randomised studies. Lancet 2007;370:2118-25. doi:10.1016/S01406736(07)61906-0

18. Fortes M del P, Machado IV, Gil G, Fernández-Mestre M, Dagher L, León RV, Bianco NE, Tassinari P. Genetic contribution of major histocompatibility complex class II region to type 1 autoimmune hepatitis susceptibility in Venezuela. Liver Int 2007;27(10):1409-16. doi:10.1111/j.1478-3231.2007.01581.x

19. Contopoulos-loannidis DG, Manoli EN, loannidis JP. Meta-analysis of the association of beta2-adrenergic receptor polymorphisms with asthma phenotypes. J Allergy Clin Immunol 2005;115:963-72. doi:10.1016/j.jaci.2004.12.1119

20. Thakkinstian A, McEvoy M, Minelli C, Gibson P, Hancox B, Duffy D, Thompson J, Hall I, Kaufman J, Leung TF, Helms PJ, Hakonarson $\mathrm{H}_{\text {, }}$ Halpi E, Navon R, Attia J. Systematic review and meta-analysis of the association between \{beta\}2-adrenoceptor polymorphisms and asthma: a HuGE review. Am J Epidemiol 2005;162(3):201-11. doi:10.1093/aje/kwi184

21. Migita O, Noguchi E, Jian Z, Shibasaki M, Migita T, Ichikawa K, Matsui A, Arinami T. ADRB2 polymorphisms and asthma susceptibility: transmisión disequilibrium test and meta-analysis. Int Arch Allergy Immunol 2004;134(2):150-7. doi:10.1159/000078648

22. Park HW, Yang MS, Park CS, Kim TB, Moon HB, Min KU, Kim YY, Cho $\mathrm{SH}$. Additive role of tiotropium in severe asthmatics and Arg16Gly in ADRB2 as a potential marker to predict response. Allergy 2009;64:778-83. doi:10.1111/j.1398-9995.2008.01876.x

23. Finkelstein Y, Garcia-Bournissen F, Hutson J, Shannon M. Polymorphism of the ADRB2 gene and response to inhaled betaagonists in children with asthma: a meta-analysis. J Asthma. 2009;46:900-5. doi:10.3109/02770900903199961

24. Lee Y, Wang S, Tsai C, Guo Y. Associations of beta2-adrenergic receptor genotypes and haplotypes with wheezing illness in Taiwanese schoolchildren. Allergy 2009; 4:1451-7. doi:10.1111/j.13989995.2009.02020.x 